\title{
BMJ Open Regional differences in tobacco smoking and lung cancer in Portugal in 2018: a population-based analysis using nationwide incidence and mortality data
}

\author{
Gonçalo Forjaz (D) , ${ }^{1,2}$ Joana Bastos, ${ }^{3}$ Clara Castro, ${ }^{4,5}$ Alexandra Mayer, ${ }^{6}$ \\ Anne-Michelle Noone, ${ }^{1}$ Huann-Sheng Chen, ${ }^{1}$ Angela B Mariotto ${ }^{1}$
}

To cite: Forjaz G, Bastos J, Castro C, et al. Regional differences in tobacco smoking and lung cancer in Portugal in 2018: a population-based analysis using nationwide incidence and mortality data. BMJ Open 2020;10:e038937. doi:10.1136/ bmjopen-2020-038937

- Prepublication history and additional material for this paper is available online. To view these files, please visit the journal online (http://dx.doi.org/10. 1136/bmjopen-2020-038937)

Received 29 March 2020 Revised 19 August 2020 Accepted 17 September 2020

Check for updates

(C) Author(s) (or their employer(s)) 2020. Re-use permitted under CC BY-NC. No commercial re-use. See rights and permissions. Published by BMJ.

For numbered affiliations see end of article.

Correspondence to

Dr Gonçalo Forjaz;

goncalo.forjaz@nih.gov

\section{ABSTRACT}

Objectives This study aims to estimate the proportion of lung cancer cases and deaths attributable to tobacco smoking in Portugal in 2018, complemented by trends in incidence and mortality, by sex and region.

Design Cancer cases for 1998-2011 and cancer deaths for 1991-2018 were obtained from populationbased registries and Statistics Portugal, respectively. We projected cases for 2018 and used reported deaths for the same year to estimate, using Peto's method, the number and proportion of lung cancer cases and deaths caused by tobacco smoking in 2018. We calculated the age-adjusted incidence and mortality rates in each year of diagnosis and death. We fitted a joinpoint regression to the observed data to estimate the annual percentage change (APC) in the rates.

Setting Portugal.

Results In 2018, an estimated 3859 cases and 3192 deaths from lung cancer were attributable to tobacco smoking in Portugal, with men presenting a population attributable fraction (PAF) of $82.6 \%(n=3064)$ for incidence and $84.1 \%(n=2749)$ for mortality, while in women those values were $51.0 \%(n=795)$ and $42.7 \%(n=443)$, respectively. In both sexes and metrics, the Azores were the region with the highest PAF and the Centre with the lowest. During 1998-2011, the APC for incidence ranged from $0.6 \%$ to $3.0 \%$ in men and $3.6 \%$ to $7.9 \%$ in women, depending on region, with mortality presenting a similar pattern between sexes.

Conclusion Exposure to tobacco smoking has accounted for most of the lung cancer cases and deaths estimated in Portugal in 2018. Differential patterns of tobacco consumption across the country, varying implementation of primary prevention programmes and differences in personal cancer awareness may have contributed to the disparities observed. Primary prevention of lung cancer remains a public health priority, particularly among women.

\section{INTRODUCTION}

Lung cancer is the most frequent cancer and the leading cause of cancer mortality worldwide. ${ }^{1}$ There were an estimated 2.1 million new cases and 1.8 million deaths in 2018, accounting for $11.6 \%$ of all cancer cases and
Strengths and limitations of this study

- This is the first population-based study to provide an estimate of the attributable fraction of tobacco consumption and lung cancer by sex and geographical region in Portugal.

- The study used incidence data obtained from population-based cancer registries covering the whole country for the 14-year period 1998-2011, and mortality data as reported from Statistics Portugal for the 28-year period 1991-2018.

- The study had to assume that the constant by which the number of cases changed annually still held in 2018.

- The study had to assume that the age-specific and sex-specific never-smoker incidence and mortality rates derived from the American Cancer Prevention Study phase II cohort are proxies for those in Portugal.

$18.4 \%$ of all cancer deaths. ${ }^{1}$ In Portugal, lung cancer ranks fourth in terms of cancer incidence and first in terms of cancer mortality, with an estimated 5284 new cases and 4671 deaths in $2018 .^{1}$

Tobacco smoking is the leading cause of lung cancer, with more than $80 \%$ of cases in Western populations being attributed to this personal habit. ${ }^{2}$ Over $70 \%$ of lung cancer deaths in men and around $55 \%$ of lung cancer deaths in women are caused by tobacco consumption. ${ }^{3}$ Tobacco smoking is a stronger aetiological risk factor for squamous cell carcinoma and small cell lung carcinoma than for adenocarcinoma, but the effect of smoking on the risk of adenocarcinoma decreases less rapidly after smoking cessation. ${ }^{4}$ Although smoking prevalence rates in Portugal have been historically low relative to other European countries, ${ }^{5}$ around $30 \%$ of men and $17 \%$ of women over 15 years of age were daily smokers in $2018 .^{6}$ 
The relative importance of any exposure as a cause of cancer in a given population can be measured by the population attributable fraction (PAF) ${ }^{7}$ This metric incorporates the prevalence of the exposure and the strength of the association between exposure and disease. ${ }^{8}$ It is defined as the proportion of cancer cases that would not have occurred if the exposure had not been present in the population. ${ }^{9}$ The PAF has been used as a guide to prioritise future cancer control activities.

Our study aims to estimate the proportion of lung cancer cases and deaths attributable to tobacco smoking in Portugal in 2018, by sex and region. To our knowledge, this is the first published study to estimate the fraction of lung cancer incidence and mortality attributable to a modifiable risk factor using incidence data for the whole country.

\section{METHODS}

Invasive lung cancer cases (International Statistical Classification of Diseases and Related Health Problems, 10th Revision code C34) by single age and region of residence were obtained for the 14-year time period 1998 through 2011 (the last year for which observed data for the whole country were available) from four population-based cancer registries: ROR-Sul (covering the southern part of mainland Portugal and the archipelago of Madeira, and representing around $45.2 \%$ of the population in 2018 (4 646150 inhabitants)); RORENO (covering the northern part of mainland Portugal (30.7\% or 3154215 inhabitants)); ROR-Centro (covering the central part of mainland Portugal (21.7\% or 2233406 inhabitants)); RORA (covering the archipelago of the Azores (2.4\% or 242846 inhabitants)). These registries provided only de-identified information, aggregated at the regional level, so approval by an ethics committee was not necessary. Only first primary lung tumours, as defined by international coding rules, ${ }^{10}$ have been included in the analysis. We obtained lung cancer deaths by sex, region, and 5-year age group for 2018 from Statistics Portugal. ${ }^{11}$ We chose the year 2018 because this is the most recent year for which our incidence projections could be validated through GLOBOCAN ${ }^{1}$ and the latest year for which official mortality data were available. Analyses were restricted to ages 35 and older to account for the latency period of smoking and lung cancer. ${ }^{12}$

We estimated the number of lung cancer cases expected to occur in Portugal in 2018. To do this, we applied incidence counts for each year in 1998-2011 to the joinpoint regression model with modified Bayes Information Criterion, with the last segment from the fitted model being used to project new cases in 2018, by sex and region. ${ }^{13}$ We assumed that the annual percentage change (APC) in the number of new cases follows a Poisson distribution and that the constant by which they change still held in 2018. This analysis was performed using the U.S. National Cancer Institute (NCI)'s Joinpoint Regression Program V.4.7.0.0. ${ }^{14}$
The number and percentage of lung cancer cases and deaths caused by tobacco smoking were estimated using the method developed by Peto and colleagues ${ }^{15}$ and refined by Parkin. ${ }^{16}$ This method is based on the assumption that tobacco smoking is by far the leading cause of lung cancer, and that the incidence (or mortality) of this disease in the absence of smoking would be small and approximately the same in all populations. To estimate the number of lung cancer cases and deaths expected in Portugal in the absence of smoking, we applied the age-specific and sex-specific never-smoker incidence and mortality rates derived from the American Cancer Prevention Study (CPS) phase II cohort ${ }^{16}{ }^{17}$ to the population of each geographical region in 2018. We assumed that nonsmoker lung cancer rates estimated in the CPS-II study are proxies for those in Portugal. We obtained population estimates for 2018, by sex, age group and geographical region of residence, from Statistics Portugal. ${ }^{18}$ We finally calculated the number of cases and deaths attributable to smoking and the corresponding PAFs by subtracting the expected cases/deaths from the number projected (incidence) and reported (mortality) in 2018. We performed a sensitivity analysis using incident data for the observed period 1998-2011. We divided this period into two 7-year (1998-2004 and 2005-2011) grouping and calculated the PAFs by sex and region (online supplemental table 1).

We complemented our analysis by generating trends in age-adjusted incidence and mortality rates for lung cancer. We used the period 1998-2011 for incidence and 19912018 for mortality. Lung cancer deaths by sex, region, and 5-year age group for 1991-2018, as well as population estimates for the same period, were obtained from Statistics Portugal. ${ }^{11}{ }^{18}$ We calculated the age-adjusted rate in each year of diagnosis and death, standardised to the European population, using NCI's Joinpoint Regression Program V.4.7.0.0. ${ }^{14}$ This program was also used to fit a joinpoint regression to the observed data to estimate the APC in the rates. We allowed a maximum of two joinpoints in the incidence model and a maximum of five joinpoints in the mortality model.

\section{Patient or public involvement}

No patients involved.

\section{Data availability}

The data that support the findings of this study are available from the regional cancer registries-ROR-Sul (https://www.encr.eu/node/280), RORENO (http:// www.ipoporto.pt/universo-ipo-porto/), ROR-Centro (http://www.ipocoimbra.min-saude.pt/) and RORA (http://www.azores.gov.pt/Portal/pt/entidades/srs$\mathrm{coa} /)$ - and are available from the authors with the permission of these registries.

\section{RESULTS}

A total of 5269 new cases of lung cancer were estimated in Portugal in 2018 (table 1), representing a 37\% departure 
Table 1 Lung cancer cases and deaths attributed to tobacco smoking by sex and region, Portugal, 2018

\begin{tabular}{|c|c|c|c|c|c|c|c|c|}
\hline \multirow[b]{2}{*}{ Region } & \multicolumn{4}{|l|}{ Incidence } & \multicolumn{4}{|l|}{ Mortality } \\
\hline & $\begin{array}{l}\text { Projected } \\
\text { cases in } \\
2018\end{array}$ & $\begin{array}{l}\text { Cases } \\
\text { expected }^{*}\end{array}$ & $\begin{array}{l}\text { Excess } \\
\text { attributable } \\
\text { cases } \dagger\end{array}$ & $\begin{array}{l}\text { PAF } \\
(\%)\end{array}$ & $\begin{array}{l}\text { Reported } \\
\text { deaths in } \\
2018 \neq\end{array}$ & $\begin{array}{l}\text { Deaths } \\
\text { expected* }\end{array}$ & $\begin{array}{l}\text { Excess } \\
\text { attributable } \\
\text { deaths } \dagger\end{array}$ & $\begin{array}{l}\text { PAF } \\
\text { (\%) }\end{array}$ \\
\hline \multicolumn{9}{|l|}{ Both sexes } \\
\hline South & 2120 & 611 & 1509 & 71.2 & 1906 & 484 & 1422 & 74.6 \\
\hline North & 2113 & 410 & 1703 & 80.6 & 1335 & 322 & 1013 & 75.9 \\
\hline Centre & 745 & 336 & 409 & 54.9 & 833 & 267 & 566 & 67.9 \\
\hline Azores & 174 & 24 & 150 & 86.2 & 139 & 19 & 120 & 86.3 \\
\hline Madeira & 117 & 28 & 89 & 76.1 & 91 & 22 & 69 & 75.8 \\
\hline Portugal & 5269 & 1410 & 3859 & 73.2 & 4305 & 1113 & 3192 & 74.1 \\
\hline \multicolumn{9}{|l|}{ Men } \\
\hline South & 1459 & 281 & 1178 & 80.7 & 1415 & 226 & 1189 & 84.0 \\
\hline North & 1533 & 188 & 1345 & 87.8 & 1044 & 150 & 894 & 85.6 \\
\hline Centre & 512 & 155 & 357 & 69.6 & 625 & 125 & 500 & 80.0 \\
\hline Azores & 124 & 11 & 113 & 91.3 & 113 & 9 & 104 & 92.0 \\
\hline Madeira & 83 & 11 & 72 & 86.4 & 71 & 9 & 62 & 87.3 \\
\hline Portugal & 3711 & 647 & 3064 & 82.6 & 3268 & 519 & 2749 & 84.1 \\
\hline \multicolumn{9}{|l|}{ Women } \\
\hline South & 661 & 330 & 331 & 50.0 & 491 & 258 & 233 & 47.5 \\
\hline North & 580 & 222 & 358 & 61.7 & 291 & 172 & 119 & 40.9 \\
\hline Centre & 233 & 181 & 52 & 22.3 & 208 & 142 & 66 & 31.7 \\
\hline Azores & 50 & 13 & 37 & 74.0 & 26 & 10 & 16 & 61.5 \\
\hline Madeira & 34 & 17 & 17 & 51.3 & 20 & 13 & 7 & 35.0 \\
\hline Portugal & 1558 & 763 & 795 & 51.0 & 1037 & 594 & 443 & 42.7 \\
\hline
\end{tabular}

*Lung cancer cases/deaths expected in a 2018 population that had never smoked.

†Excess lung cancer cases/deaths attributable to tobacco smoking in 2018.

¥Source: Statistics Portugal.

PAF, population attributable fraction.

from the 3846 new cases reported in 2011, which was the last year of observed data for the whole country. For comparison, GLOBOCAN estimated a total of 5284 new cases in 2018. ${ }^{1}$ Of those projected in $2018,73.2 \%$ (3859 cases) were attributable to tobacco smoking, with men presenting a PAF of $82.6 \%$ (3064 cases) and women a PAF of $51.0 \%$ (795 cases). In the same year, a total of 4305 deaths from lung cancer were reported by Statistics Portugal (table 1), with an overall PAF of $74.1 \%$ (3192 deaths) for tobacco smoking (84.1\% or 2749 deaths in men and $42.7 \%$ or 443 deaths in women). By age, the highest PAFs in incidence and mortality were observed in men and women between 45 and 64 years.

The Azores were the region showing the highest PAFs (table 2). In men, around $91.3 \%$ of lung cancer cases and $92.0 \%$ of lung cancer deaths were attributable to tobacco smoking, while in women those values were $74.0 \%$ and $61.5 \%$, respectively. The Centre was the region presenting the lowest PAFs (table 2). In men, around $69.6 \%$ of lung cancer cases and $80.0 \%$ of lung cancer deaths were attributable to tobacco smoking, while in women those values were $22.3 \%$ and $31.7 \%$, respectively.

The Azores presented the highest age-adjusted rates in men and women throughout most of the incidence and mortality periods, although rates for women from the South have slightly surpassed those for women from the Azores in recent years (figure 1). Conversely, the Centre presented the lowest age-adjusted rates throughout most of the same analysis periods. Among men, the APC in the incidence period ranged from $0.6 \%(95 \%$ CI $0.1 \%$ to $1.2 \%$ ) in the South to $3.0 \%$ (2.1\% to $3.8 \%$ ) in the North, while in the mortality period the APC ranged from $0.3 \%$ in the South and North $(0.1 \%$ to $0.5 \%)$ to $0.7 \%(0.4 \%$ to $1.0 \%)$ in the Centre. Among women, the APC in the incidence period ranged from $3.6 \%(1.6 \%$ to $5.6 \%)$ in the Centre to $7.9 \%$ (3.9\% to $12.2 \%$ ) in Madeira, while in the mortality period the last segment of the APC ranged from $1.1 \%(0.7 \%$ to $1.5 \%)$ in the North to $3.5 \%$ (2.9\% to $4.1 \%)$ in the South. 
Table 2 Lung cancer cases and deaths attributed to tobacco smoking by sex and age group, Portugal, 2018

\begin{tabular}{|c|c|c|c|c|c|c|c|c|}
\hline \multirow[b]{2}{*}{ Age group (years) } & \multicolumn{4}{|l|}{ Incidence } & \multicolumn{4}{|l|}{ Mortality } \\
\hline & $\begin{array}{l}\text { Projected } \\
\text { cases in } \\
2018\end{array}$ & $\begin{array}{l}\text { Cases } \\
\text { expected }\end{array}$ & $\begin{array}{l}\text { Excess } \\
\text { attributable } \\
\text { cases } \dagger\end{array}$ & $\begin{array}{l}\text { PAF } \\
\text { (\%) }\end{array}$ & $\begin{array}{l}\text { Reported } \\
\text { deaths in } \\
2018 \ddagger\end{array}$ & $\begin{array}{l}\text { Deaths } \\
\text { expected* }\end{array}$ & $\begin{array}{l}\text { Excess } \\
\text { attributable } \\
\text { deaths } \dagger\end{array}$ & $\begin{array}{l}\text { PAF } \\
\text { (\%) }\end{array}$ \\
\hline \multicolumn{9}{|l|}{ Both sexes } \\
\hline $35-44$ & 136 & 51 & 85 & 62.5 & 54 & 33 & 21 & 38.9 \\
\hline $45-54$ & 776 & 104 & 672 & 86.6 & 296 & 72 & 224 & 75.7 \\
\hline $55-64$ & 1409 & 202 & 1207 & 85.7 & 945 & 148 & 797 & 84.3 \\
\hline$\geq 65$ & 2948 & 1054 & 1894 & 64.2 & 3010 & 860 & 2150 & 71.4 \\
\hline Total & 5269 & 1410 & 3859 & 73.2 & 4305 & 1113 & 3192 & 74.1 \\
\hline \multicolumn{9}{|l|}{ Men } \\
\hline $35-44$ & 68 & 21 & 47 & 69.1 & 35 & 14 & 21 & 60 \\
\hline $45-54$ & 522 & 44 & 478 & 91.6 & 213 & 32 & 181 & 85 \\
\hline $55-64$ & 999 & 92 & 907 & 90.8 & 738 & 70 & 668 & 90.5 \\
\hline$\geq 65$ & 2122 & 490 & 1632 & 76.9 & 2282 & 403 & 1879 & 82.3 \\
\hline Total & 3711 & 647 & 3064 & 82.6 & 3268 & 519 & 2749 & 84.1 \\
\hline \multicolumn{9}{|l|}{ Women } \\
\hline $35-44$ & 68 & 30 & 38 & 55.9 & 19 & 19 & 0 & 0 \\
\hline $45-54$ & 254 & 60 & 194 & 76.4 & 83 & 40 & 43 & 51.8 \\
\hline $55-64$ & 410 & 110 & 300 & 73.2 & 207 & 78 & 129 & 62.3 \\
\hline$\geq 65$ & 826 & 564 & 262 & 31.7 & 728 & 457 & 271 & 37.2 \\
\hline Total & 1558 & 763 & 795 & 51 & 1037 & 594 & 443 & 42.7 \\
\hline
\end{tabular}

*Lung cancer cases/deaths expected in a 2018 population that had never smoked.

†Excess lung cancer cases/deaths attributable to tobacco smoking in 2018.

$\ddagger$ Source: Statistics Portugal.

PAF, population attributable fraction.

\section{DISCUSSION}

In this study, we used Peto's method to estimate the proportion of lung cancer cases and deaths attributable to tobacco smoking in Portugal in 2018. We estimated that 3859 new cases (3064 in men and 795 in women) and 3192 deaths (2749 in men and 443 in women) were caused by tobacco smoking, corresponding to an overall PAF of $73.2 \%$ for incidence $(82.6 \%$ in men, $51.0 \%$ in women) and $74.1 \%$ for mortality $(84.1 \%$ in men, $42.7 \%$ in women). Peto's method is valid only in populations in which smoking prevalence is high, as is the case in most developed countries (including Portugal), and it has the advantage of not requiring risk factor exposure data. ${ }^{7}$ Many studies have used this method to quantify the lung cancer burden attributable to tobacco smoking. ${ }^{16-23}$ Our overall results for men are similar to those from Australia reported for the year $2010(83.5 \%),{ }^{21}$ to those from the UK for the year $2015(85 \%)^{16}$ and, to some extent, to
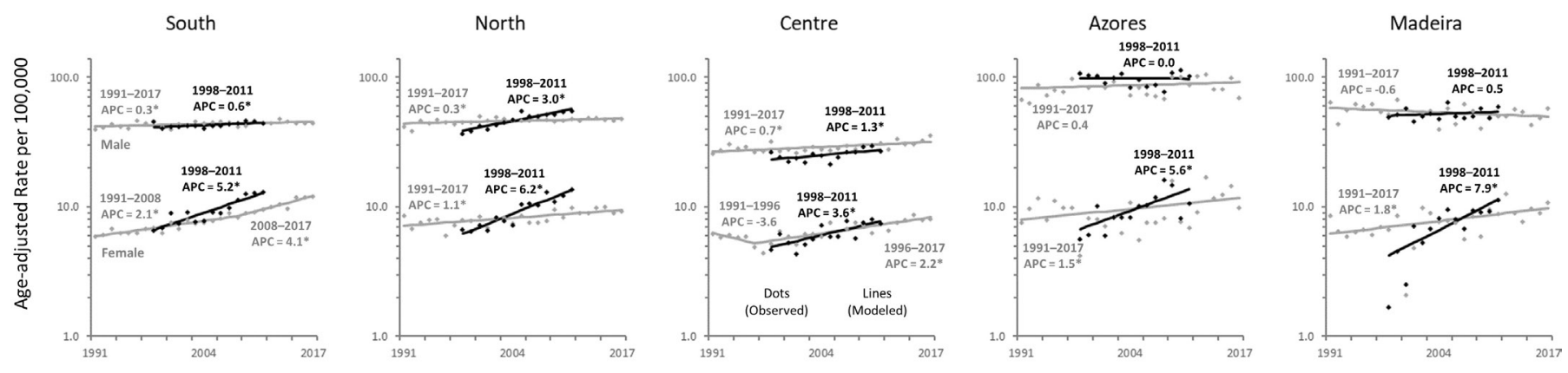

Figure 1 Trends in age-adjusted incidence (black dots and lines) and mortality (grey dots and lines) rates for lung cancer by sex and region, Portugal, 1991-2018. The rates are plotted on a log scale. APC, annual percentage change. ${ }^{*}$ The APC is significantly different from zero $(p<0.05)$. 
those from Vietnam for the year 2008 (90.9\%). ${ }^{19}$ Results for women, however, are less comparable. For example, Parkin reported an overall PAF of $80 \%$ for the UK in $2015,{ }^{16}$ while we estimated a PAF of $51 \%$ (table 1 ). These differences would point towards a higher level of tobacco consumption among British women. However, limitations in Peto's method may also impact PAF estimates, in both men and women. For instance, the cohort study on which this method relies-CPS-II-was not completely representative of the population as most of its participants were from the middle class. ${ }^{24}$ This could underestimate lung cancer mortality in non-smokers and, in turn, lead to an overestimation of lung cancer mortality attributable to tobacco consumption. ${ }^{25}$ The method heavily depends on the assumption that CPS-II estimates of lung cancer death rates for smokers and non-smokers can be applied to other countries and across time. ${ }^{26}$ Ascertaining the extent to which these assumptions underestimate or overestimate our results is beyond the scope of this study. In addition, it would be difficult to assess that question because a reference study from Portugal is not available for comparison.

The PAFs varied greatly among regions. The Azores presented the highest PAFs in men and women. In a recent survey, this region showed the highest smoking rate among men aged 15 years and older $(34.7 \%){ }^{27}$ Compared with other regions, men and women in the Azores also smoked more cigarettes per day (23 and 16 , respectively). In addition, the mean starting age of smoking in men was 15 years in the Azores, compared with 17 years in the other regions. Trends in age-adjusted rates for incidence and mortality are consistent with these results (figure 1).

Conversely, the lowest PAFs were observed in the Centre, again in both sexes. The Centre has historically been the region presenting the lowest incidence and mortality rates for lung cancer (figure 1 ). From the analysis of data concerning mortality to incidence ratios (online supplemental table 2), incompleteness was noted for this region. The proportion of lung cancer cases attributed to smoking is ultimately related to the incidence burden, which in turn depends on completeness. This could partially explain the lower PAFs observed for the Centre. However, trends in age-adjusted mortality rates, which are obtained from a source independent of the registry, mirror those for incidence (figure 1). Therefore, we would not expect to see much difference in incidence rates for the Centre, had the level of completeness been higher. Also, the Centre presented the lowest prevalence of tobacco smoking in each of the five National Health Surveys conducted to date. ${ }^{28}$ The region was a pioneer in developing and implementing successful primary prevention initiatives at the community level, mainly through the regional branch of the Portuguese League Against Cancer. ${ }^{29-32}$ Part of the lower disease risk might therefore be explained by healthier lifestyles and improved cancer awareness and control among people from the Centre.
Figures for the remaining regions lie between those presented for the Azores and those shown for the Centre. The South, for example, is vast and heterogeneous, including the highly populated metropolitan area of Lisbon, the strongly rural and sparsely populated Alentejo, and the southernmost zone of the country known as the Algarve. ${ }^{33}$ Due to the differences and asymmetries observed in the peoples of this vast region, it is difficult to identify plausible reasons for the results. A more granular analysis at the district level is warranted to elucidate the patterns seen in each region.

The highest PAFs were observed in age groups 45-54 and 55-64 years, irrespective of sex. We cannot attribute causality or association, as our study is based on descriptive data, but these results are consistent with studies addressing the prevalence of smoking in Portugal and the latency period. A study by Carreira and colleagues estimated that smoking prevalence in Portugal was highest among those aged 30 years or younger and those between 31 and 50 years. ${ }^{34}$ The latency period for smoking and lung cancer is not well established but may vary between 7 and 33 years, ${ }^{35}$ depending on factors such as exposure duration (starting age) and smoking intensity (cigarettes per day) ${ }^{36}$ Smokers in their 20 s, 30s and 40 s, when consumption peaks, would therefore be the people who later make up the immense pool of those who develop and die from lung cancer in their 40s, 50s and 60s. Worth noting is that contemporary figures for lung cancer incidence always reflect cumulative exposure to carcinogens in tobacco smoke, ${ }^{16}$ which varies according to prevalence and over time, and that certainly applies to Portugal.

There are still substantial differences between sexes with respect to daily tobacco consumption in Portugal overall. For instance, in 2018, the smoking prevalence was $30 \%$ in men and $17 \%$ in women. ${ }^{6}$ Since 1987 , and despite these differences, prevalence has been decreasing among men, while increasing among women, especially in those at younger ages. ${ }^{628}$ Our results are in line with this trend. Figure 1 shows how cigarette smoking uptake among women has been influencing lung cancer incidence and mortality trends across all regions. More girls (5000) than boys (4100) between the ages of 10 and 14 years are also daily smokers. ${ }^{37}$ This is of particular concern because of tobacco smoking's impact on women's health and the risk of prenatal and childhood exposure. ${ }^{5}$

Portugal has made progress on tobacco control in the last 10-15 years. The first step was taken when Portugal ratified the WHO Framework Convention on Tobacco Control (FCTC) on 8 November 2005. ${ }^{38}$ This was followed by a law approving measures to protect citizens from involuntary exposure to tobacco smoke-Law No. $37 / 2007$ - which took effect on 1 January $2008 .{ }^{39}$ Several control actions followed the law's implementation, such as a ban on advertisements on TV and radio, in newspapers and outdoors, and fines for violating implemented norms. Funds for enforcement of the law are still lacking, however. ${ }^{3740}$ 
To comply with the FCTC, in 2012 the Ministry of Health launched "The National Program for Smoking Prevention and Tobacco Control" (PNPCT), ${ }^{41}$ whose strategies are based on the FCTC guidelines and the MPOWER measures. WHO introduced the latter in 2007 to help countries reduce demand for tobacco products. ${ }^{42}$ As noted in the latest report submitted by Portugal to FCTC,$^{43}$ the four main strategies of the PNPCT are (1) preventing initiation of consumption in adolescents and young people; (2) promoting smoking cessation, with a particular focus on smokers under 40 years of age, in women and during pregnancy; (3) protecting people from environmental tobacco smoke (secondhand smoke); and (4) reducing health inequalities, including regional disparities in prevention, treatment and tobacco control. Regional differences in prevention and treatment are one of the main areas of concern identified by the PNPCT. Future research is needed to elucidate how each Regional Health Administration, including the Autonomous Regions of the Azores and Madeira, is implementing the strategies defined by the PNPCT.

In 2014, Portugal also transposed into national legislation the Directive 2014/40/EU of the European Parliament and of the Council, which aims to harmonise all laws enacted from the Member States concerning the manufacture, presentation and sale of tobacco and related products. ${ }^{44}$ More recently, Law No. 63/2017 incorporated the new forms of tobacco, such as electronic cigarettes, into the concept of smoking. ${ }^{45}$ With all of these laws in place, Portugal progressed from sporadic information and education about the hazards of tobacco to structured programmes encompassing all stages of the tobacco control continuum.

Raising taxes to increase the price of tobacco products is the single most effective tobacco control measure. ${ }^{46}$ WHO recommends that at least $70 \%$ of the retail price of cigarettes come from excise taxes, that is, those levied on goods that are considered unnecessary. ${ }^{37}$ Barriers to raising taxes on tobacco are often related to a conflict of interest between policies intended to promote health and well-being and the commercial interests of the tobacco industry. ${ }^{47}$ Often, the latter takes precedence over the former, and that may have been why Portugal dropped out of the group of high-income countries that have raised taxes sufficiently to reach WHO's benchmark. ${ }^{46}$ As of 2018, the excise tax for tobacco products sold in Portugal was, on average, $53 \% .^{48}$

Our study has the usual limitations of descriptive epidemiology. For example, a lack of individual-level risk factor data permits only ecological correlations on the variables under analysis. ${ }^{49}$ In addition, our study focused solely on the PAF. Despite its usefulness, this metric is insufficient for providing a more comprehensive assessment of the lung cancer burden attributable to smoking. Ideally, this assessment should include estimation of smoking-attributable lung cancer disability-adjusted lifeyears (DALYs), modelling of the joint effects of different tobacco forms on lung cancer and estimation of the potential impact fraction. ${ }^{36} 50$ The latter measures the proportion of disease incidence that could be prevented under a hypothetical intervention scenario.

Regarding DALYs, the Global Burden of Disease (GBD) study estimated that smoking contributed to $73.0 \%$ of lung cancer deaths in men and $31.5 \%$ in women in Portugal in 2017. ${ }^{51}$ These values cannot be directly compared with those in our study $(84.1 \%$ in men and $42.7 \%$ in women; table 2) because the methods are not entirely consistent with one another. Nevertheless, the high DALYs from GBD and PAFs from our study underscore how substantially tobacco smoking contributes to lung cancer mortality.

Some of our analyses were based on low counts (ie, Azores and Madeira) and the report of new cases referred to 2011, which required us to forecast 7 years of incidence data and make some assumptions about the constant by which the number of cases changed annually. In addition, we had to rely on the assumptions of Peto's method and that non-smoker lung cancer rates estimated in the CPS-II study would also apply to Portugal. Nevertheless, our sensitivity analysis did not change main results: in men, the Azores ranked first in terms of cases attributable to tobacco and the Centre ranked last (online supplemental table 1); in women, we could not calculate the PAFs in some of the regions due to low counts, and for those where PAFs were estimated, we recommend caution in interpretation. Only more recently have incidence rates in women probably attained a threshold after which Peto's method is appropriate for estimation of PAFs, as this method is valid only in populations where smoking prevalence is high. Our estimates are somewhat conservative, too, as they did not include involuntary tobacco smoke exposure (environmental tobacco smoke; secondhand smoke) or other types of tobacco use, such as electronic cigarettes, which are becoming more popular among youth. Finally, differences among regions are, to some extent, related to the level of completeness and case ascertainment in each cancer registry. However, trends in age-adjusted mortality rates showed patterns similar to those for incidence (figure 1), with the Azores presenting the highest values and the Centre the lowest. Notwithstanding these limitations, our results are representative of the whole country, and our incidence projections for 2018 are very close to those reported by GLOBOCAN for the same year. ${ }^{1}$

In conclusion, our study is a contribution to monitoring the smoking-attributable incidence and mortality burden of lung cancer in Portugal. It provides useful information about tobacco-related surveillance health data, as mandated by the WHO FCTC and specified in one of the MPOWER measures ("Monitor tobacco use and prevention policies"). ${ }^{42}$ Our study also highlights health inequalities across the country by depicting regional differences in PAFs and in the incidence and mortality burdens of lung cancer. Finally, although much has been accomplished in the past 10-15 years with respect to tobacco control, far more needs to be done to implement the provisions of the WHO FCTC fully: taxation 
could be increased, funds for law enforcement improved, educational programmes enforced, smoke-free places expanded, cessation programmes scaled up and regional health disparities addressed.

\section{Author affiliations}

${ }^{1}$ Division of Cancer Control and Population Sciences, National Cancer Institute, Rockville, Maryland, USA

${ }^{2}$ Azores Oncological Centre, Azores, Portugal

${ }^{3}$ Centre Region Cancer Registry, Francisco Gentil Portuguese Institute for Oncology of Coimbra, Coimbra, Portugal

${ }^{4}$ Northern Region Cancer Registry, Francisco Gentil Portuguese Institute for Oncology of Porto, Porto, Portugal

${ }^{5}$ EPIUnit, Institute of Public Health, University of Porto, Porto, Portugal

${ }^{6}$ Southern Region Cancer Registry, Francisco Gentil Portuguese Institute for Oncology of Lisbon, Lisboa, Portugal

Acknowledgements GF is supported by an appointment to the National Cancer Institute Research Participation Program administered by the 0ak Ridge Institute for Science and Education through an interagency agreement between the U.S. Department of Energy and the National Institutes of Health. The authors would like to thank Ms Susan Scott from the National Cancer Institute for manuscript editing assistance and the regional cancer registries for providing the data used in this study.

Contributors GF, JB, CC, AM and ABM were responsible for design of the study; acquisition, analysis and interpretation of data; drafting and revising for important intellectual content; final approval of the version to be published; and agreement to be accountable for the accuracy and integrity of any part of the work. A-MN and $\mathrm{H}-\mathrm{SC}$ were involved in analysis and interpretation of data, drafting and revising of content, final approval of the version to be published, and agreement to be accountable for the accuracy and integrity of any part of the work.

Funding The authors have not declared a specific grant for this research from any funding agency in the public, commercial or not-for-profit sectors.

Competing interests None declared.

Patient consent for publication Not required.

Provenance and peer review Not commissioned; externally peer reviewed.

Data availability statement Data are available on reasonable request. The data that support the findings of this study are available from the regional cancer registries—ROR-Sul (https://www.encr.eu/node/280), RORENO (http://www. ipoporto.pt/universo-ipo-porto/), ROR-Centro (http://www.ipocoimbra.min-saude. pt/) and RORA (http://www.azores.gov.pt/Portal/pt/entidades/srs-coa/)—and are available from the authors with the permission of these registries.

Supplemental material This content has been supplied by the author(s). It has not been vetted by BMJ Publishing Group Limited (BMJ) and may not have been peer-reviewed. Any opinions or recommendations discussed are solely those of the author(s) and are not endorsed by BMJ. BMJ disclaims all liability and responsibility arising from any reliance placed on the content. Where the content includes any translated material, BMJ does not warrant the accuracy and reliability of the translations (including but not limited to local regulations, clinical guidelines, terminology, drug names and drug dosages), and is not responsible for any error and/or omissions arising from translation and adaptation or otherwise.

Open access This is an open access article distributed in accordance with the Creative Commons Attribution Non Commercial (CC BY-NC 4.0) license, which permits others to distribute, remix, adapt, build upon this work non-commercially, and license their derivative works on different terms, provided the original work is properly cited, appropriate credit is given, any changes made indicated, and the use is non-commercial. See: http://creativecommons.org/licenses/by-nc/4.0/.

ORCID iD

Gonçalo Forjaz http://orcid.org/0000-0001-8855-2042

\section{REFERENCES}

1 Bray F, Ferlay J, Soerjomataram I, et al. Global cancer statistics 2018: GLOBOCAN estimates of incidence and mortality worldwide for 36 cancers in 185 countries. CA Cancer J Clin 2018;68:394-424.
2 Secretan B, Straif K, Baan R, et al. A review of human carcinogenspart E: tobacco, areca nut, alcohol, coal smoke, and salted fish. Lancet Oncol 2009;10:1033-4.

3 O'Keeffe LM, Taylor G, Huxley RR, et al. Smoking as a risk factor for lung cancer in women and men: a systematic review and metaanalysis. BMJ Open 2018;8:e021611.

4 Hung RJ, Gazdar AF. Lung cancer. In: Wild CP, Weiderpass E, Stewart BW, eds. World cancer report: cancer research for cancer prevention. Lyon, France: International Agency for Research on Cancer, 2020: 299-309.

5 Precioso J, Calheiros J, Pereira D, et al. [Prevalence and smoking trends in Portugal and Europe]. Acta Med Port 2009;22:335-48.

6 WHO. Global report on trends in prevalence of tobacco smoking 2000-2025. Second ed. Geneva: World Health Organization, 2018.

7 Shield KD, Parkin DM, Whiteman DC, et al. Population attributable and preventable fractions: cancer risk factor surveillance, and cancer policy projection. Curr Epidemiol Rep 2016;3:201-11.

8 Keum N, Song M, Giovannucci EL. Obesity and body composition. In: Thun M, Linet MS, Cerhan JR, et al, eds. Schottenfeld and Fraumeni cancer epidemiology and prevention. 4th ed. New York: Oxford University Press, 2018: 351-76.

9 Franceschi S, El-Serag HB, Forman D, et al. Infectious agents. In: Thun M, Linet MS, Cerhan JR, et al, eds. Schottenfeld and Fraumeni cancer epidemiology and prevention. 4th ed. New York: Oxford University Press, 2018: 433-60.

10 Working Group Report. International rules for multiple primary cancers (ICD-0 third edition). Eur J Cancer Prev 2005;14:307-8.

11 Portugal S. Mortality rate due to malignant neoplasms (\%o) by place of residence (NUTS - 2013); Annual - Statistics Portugal, Mortality by causes of death. Available: https://www.ine.pt/; [Accessed 17 Jun 2020].

12 Ezzati M, Lopez AD, Rodgers AA, et al. Comparative quantification of health risks: global and regional burden of disease attributable to selected major risk factors. Geneva: World Health Organization, 2004.

13 Zhu L, Pickle LW, Ghosh K, et al. Predicting US- and state-level cancer counts for the current calendar year: Part II: evaluation of spatiotemporal projection methods for incidence. Cancer 2012;118:1100-9.

14 Joinpoint Regression Program version 4.7.0.0. Surveillance Research Program, Division of Cancer Control and Population Sciences, National Cancer Institute, (February, 2019). Available: https:// surveillance.cancer.gov/joinpoint/

15 Peto R, Lopez AD, Boreham J, et al. Mortality from tobacco in developed countries: indirect estimation from national vital statistics. Lancet 1992;339:1268-78.

16 Parkin DM. 2. Tobacco-attributable cancer burden in the UK in 2010. Br J Cancer 2011;105 Suppl 2:S6-13.

17 Thun MJ, Henley SJ, Burns D, et al. Lung cancer death rates in lifelong nonsmokers. J Natl Cancer Inst 2006;98:691-9.

18 Portugal S, Portugal S. Annual estimates of resident population: resident population (no.) by place of residence (NUTS - 2013), sex and age group. Available: https://www.ine.pt/; [Accessed 17 Jun 2020].

19 Norman RE, Vos T, Barendregt JJ, et al. Mortality attributable to smoking in Vietnamese men in 2008. Prev Med 2013;57:232-7.

20 Ribassin-Majed L, Hill C. Trends in tobacco-attributable mortality in France. Eur J Public Health 2015;25:824-8.

21 Pandeya N, Wilson LF, Bain CJ, et al. Cancers in Australia in 2010 attributable to tobacco smoke. Aust N Z J Public Health 2015;39:464-70.

22 Menvielle G, Kulhánová I, Bryère J, et al. Tobacco-attributable burden of cancer according to socioeconomic position in France. Int $J$ Cancer 2018; 143:478-85.

23 Soerjomataram I, Shield K, Marant-Micallef C, et al. Cancers related to lifestyle and environmental factors in France in 2015. Eur J Cancer 2018;105:103-13.

24 Pérez-Ríos M, Montes A. Methodologies used to estimate tobaccoattributable mortality: a review. BMC Public Health 2008;8:22.

25 Sterling TD, Rosenbaum WL, Weinkam JJ. Risk attribution and tobacco-related deaths. Am J Epidemiol 1993;138:128-39.

26 Preston SH, Glei DA, Wilmoth JR. A new method for estimating smoking-attributable mortality in high-income countries. Int $J$ Epidemiol 2010;39:430-8.

27 INE. Inquérito Nacional de Saúde 2014. Lisboa, Portugal: Instituto Nacional de Estatística, 2016. https://www.dgs.pt/em-destaque/ inquerito-nacional-de-saude.aspx;

28 Leite A, Machado A, Pinto S, et al. Caraterísticas sociodemográficas DOS fumadores em Portugal continental: análise comparativa DOS Inquéritos Nacionais de Saúde (1987, 1995/1996, 1998/1999, 2005/2006 E 2014. Lisboa: Instituto Nacional de Saúde Doutor Ricardo Jorge (INSA, IP), 2017. 
29 Bettencourt Cruz D, Rocha Alves JG, Rodrigues VL. Le Dépistage Du cancer Du sein dans La région centre Du Portugal. Pathol Biol 1991;39:848-9.

30 Alves JG, Cruz DB, Rodrigues VL, et al. Breast cancer screening in the central region of Portugal. Eur J Cancer Prev 1994;3 Suppl 1:49-53.

31 Bastos J, Peleteiro B, Gouveia J, et al. The state of the art of cancer control in 30 European countries in 2008. Int $J$ Cancer 2010;126:NA-15.

32 Camacho I, Reis M, Santos T, et al. Diferenças regionais nos comportamentos de saúde e de risco dos adolescentes portugueses. Psic, Saúde \& Doenças 2016;17:368-81.

33 ROR-Sul. Registo Oncológico Nacional 2009. Lisboa, Portugal: Instituto Português de Oncologia de Lisboa Francisco Gentil, E.P.E, Lisboa.2015.

34 Carreira H, Pereira M, Azevedo A, et al. Trends in the prevalence of smoking in Portugal: a systematic review. BMC Public Health 2012;12:958.

35 Poirier AE, Grundy A, Khandwala F, et al. Cancer incidence attributable to tobacco in Alberta, Canada, in 2012. CMAJ Open 2016;4:E578-87.

36 Brenner DR, Friedenreich CM, Ruan Y, et al. The burden of cancer attributable to modifiable risk factors in Canada: methods overview. Prev Med 2019;122:3-8.

37 Drope J, Schluger NW, Cahn Z, et al. The tobacco atlas - country profile: Portugal. Atlanta, Georgia: American Cancer Society and vital strategies, 2018. Available: https://tobaccoatlas.org/country/ portugal/ [Accessed 17 Jun 2020].

38 WHO. WHO framework convention on tobacco control. Geneva, Switzerland: World Health Organization, 2003. Available: http://www. who.int/fctc/en/index.html; [Accessed 17 Jun 2020].

39 n L. ${ }^{\circ} 37 / 2007$ de 14 de Agosto: Aprova normas para a protecção dos cidadãos da exposição involuntária ao fumo do tabaco e medidas de redução da procura relacionadas com a dependência e a cessação do seu consumo. Diário da República n. ${ }^{\circ}$ 156/2007, Série I de 2007-08-14.. Available: https://dre.pt/ [Accessed 17 Jun 2020].

40 Ravara S, Filho H, Faria P, et al. Tobacco control policy-making in Portugal: vested interests or public health? Tob Prev Cessat $2015 ; 1: 3$.

41 n D. ${ }^{\circ} 404 / 2012$ de 13 de Janeiro: Determina quais os programas de saúde prioritários a desenvolver pela Direção-Geral dA Saúde (DGS)
Diário dA República n. ${ }^{\circ}$ 10/2012, Série II de 2012-01-13. Available: https://dre.pt/ [Accessed 17 Jun 2020].

42 WHO. WHO report on the global tobacco epidemic, 2008: the MPOWER package. Geneva, Switzerland: World Health Organization, 2008. Available: https://www.who.int/tobacco/mpower/mpower report_full_2008.pdf [Accessed 17Jun 2020].

$43 \mathrm{WHO}$. Core questionnaire of the reporting instrument of WHO FCTC Geneva, Switzerland: World Health Organization, 2018. Available: https://untobaccocontrol.org/impldb/wp-content/uploads/Portugal_ 2018 report.pdf [Accessed 17 Jun 2020].

44 Official Journal L 127. Directive 2014/40/EU of the European Parliament and of the Council on the approximation of the laws, regulations and administrative provisions of the member states concerning the manufacture, presentation and sale of tobacco and related products and repealing directive 2001/37/EC, 2014. Available: https://eur-lex.europa.eu/legal-content/EN/TXT/PDF/?uri=CELEX: 32014L0040\&from=EN; [Accessed 17 Jun 2020].

45 n L. ${ }^{\circ} 63 / 2017$ de 3 de Agosto: Abrange no conceito de fumar os novos produtos do tabaco sem combustão que produzam aerossóis, vapores, gases ou partículas inaláveis e reforça as medidas a aplicar a estes novos produtos em matéria de exposição ao fumo ambiental, publicidade e promoção, procedendo segunda alteração Lei $n .^{\circ}$ 37/2007, de 14 de agosto. Diário da República n. ${ }^{\circ}$ 149/2017, Série I de 2017-08-03. Available: https://dre.pt/ [Accessed 17 Jun 2020]

46 WHO. WHO report on the global tobacco epidemic, 2019. Geneva, Switzerland: World Health Organization, 2019. Available: https:// www.who.int/tobacco/global_report/en/ [Accessed 17 Jun 2020].

47 Costa A, Cortes M, Sena C, et al. Equity-focused health impact assessment of Portuguese tobacco control legislation. Health Promot Int 2018;33:279-87.

48 WHO. WHO report on the global tobacco epidemic, 2019 - country profile: Portugal. Geneva, Switzerland: World Health Organization, 2019. Available: https://www.who.int/tobacco/surveillance/policy/ country profile/prt.pdf [Accessed 17 Jun 2020].

49 Wakelee HA, Chang ET, Gomez SL, et al. Lung cancer incidence in never smokers. J Clin Oncol 2007;25:472-8.

50 Bilano VLF, Borja MP, Cruz EL, et al. Smoking-attributable burden of lung cancer in the Philippines. Tob Control 2015;24:263-8.

51 IHME. Global Burden of Disease Compare database. Seattle, Washington: Institute for Health Metrics and Evaluation, 2020 Available: https://vizhub.healthdata.org/gbd-compare/ [Accessed 17 Jun 2020]. 